\title{
Advances in domestication of indigenous fruit trees in the West African Sahel
}

\author{
Anders Ræbild • Anders Søndergård Larsen · Jan Svejgaard Jensen • \\ Moussa Ouedraogo $\cdot$ Sitske De Groote $\cdot$ Patrick Van Damme • \\ Jules Bayala • Boukary Ousmane Diallo • Haby Sanou• \\ Antoine Kalinganire $\cdot$ Erik Dahl Kjaer
}

Received: 20 August 2009/Accepted: 19 November 2010/Published online: 2 December 2010

(C) The Author(s) 2010. This article is published with open access at Springerlink.com

\begin{abstract}
Fruit trees play an important nutritional role for livelihoods of rural people in the West African Sahel through provision of energy and nutrients such as vitamins, minerals, and proteins. Research on the domestication of local fruit trees has started recently through projects concentrating on some of the most important indigenous species of dry West Africa, i.e. Adansonia digitata, Parkia biglobosa, Tamarindus indica, Vitellaria paradoxa and Ziziphus mauritiana. We present a status of finalised and ongoing domestication research with the aim of defining research gaps that would need to be covered by future research activities to obtain higher yields and better quality fruits. Germplasm collection in central West Africa has been intense compared to elsewhere in the species' distribution areas, but conservation status of the material is poor since it is only planted in few trials. Knowledge of genetic parameters, especially for fruit traits, is almost absent, but characterisation of genotypes is underway for some of the species. Mating systems and patterns are still unknown for many species. Efficient vegetative propagation based on simple techniques was shown to be possible for all species except $P$. biglobosa. In
\end{abstract}

A. Ræbild $(\bowtie) \cdot$ A. S. Larsen · J. S. Jensen · M. Ouedraogo · E. D. Kjaer

Centre for Forest, Landscape and Planning, University of Copenhagen, Rolighedsvej 23, 1958

Frederiksberg C, Denmark

e-mail: are@life.ku.dk

M. Ouedraogo

Centre National de Semences Forestières, 01 BP 2682, Ouagadougou 01, Burkina Faso

S. De Groote · P. Van Damme

Laboratory for Tropical and Subtropical Agronomy and Ethnobotany, Department of Plant Production,

Ghent University, Coupure Links 653, 9000 Ghent, Belgium

J. Bayala $\cdot$ A. Kalinganire

ICRAF SAHEL c/o ICRISAT, BP 320, Bamako, Mali

B. O. Diallo

Institut National de l'Environnement et de la Recherche Agronomique, 03 BP 7047, Ouagadougou 03, Burkina Faso

H. Sanou

Institut d'Economie Rurale, BP 258, Bamako, Mali 
order to secure immediate as well as long term gains, we recommend combining clonal propagation of selected plus individuals with recombination and breeding of selected genotypes. We discuss whether local institutions in the Sahel have the financial capacity to carry out long term breeding programmes, and suggest that efforts should be made to find new ways of disseminating improved germplasm.

\section{Keywords Adansonia digitata $\cdot$ Parkia biglobosa $\cdot$ Tamarindus indica $\cdot$ Vitellaria paradoxa $\cdot$ Ziziphus mauritiana $\cdot$ Domestication}

\section{Introduction}

Domestication is a man-driven process involving selection processes rendering the target species increasingly useful to human beings by increasing the yield and/or quality of whatever product they produce. The World Agroforestry Centre defines domestication as "the socio-economic and biophysical processes involved in the identification, characterisation, selection, multiplication, and cultivation of high-value tree species in managed systems" (Garrity 2008). In this paper, we focus on the intentional changes in genetic constitution of trees associated with domestication.

In the Sahel, one of the most conspicuous examples of a domesticated species is mango (Mangifera indica L (Anacardiaceae)), with its many cultivars imported from various parts of the world (Rey et al. 2004). Compared to this, local fruit tree species have only undergone intentional selection to a limited degree, and most of them must be characterised as being undomesticated or semi-domesticated in the genetic sense of the word. Selection in favour of superior trees by farmers may slowly have improved the productivity of the species as e.g. suggested for Vitellaria paradoxa C.F. Gaertn (Sapotaceae) by Lovett and Haq (2000), but not to an extent that differences between improved and unimproved trees are easily observed. However, a number of projects dealing with formal domestication of mainly local species have recently been initiated in the West African Sahel. These species include $V$. paradoxa, Adansonia digitata L. (Malvaceae), Parkia biglobosa (Jacq) Benth (Fabaceae), Tamarindus indica L (Fabaceae), and Ziziphus mauritiana Lam (Rhamnaceae). Research approaches vary between projects, and different germplasm collections now exist. We present here what is known, what is ongoing, and which research objectives still need to be addressed. We will discuss (i) the potential of domesticating traditional Sahelian West African fruit trees, (ii) strategies for effective management of the genetic resources, (iii) lack of knowledge about key processes of domestication, and (iv) the current state of domestication of a number of selected species from the Sahel. We deal with programmes carried out at national and regional levels, and will not discuss local participatory tree breeding programmes. For information about this issue, the reader is referred to e.g. Tchoundjeu et al. (2008).

\section{Potentials in domestication}

Genetic improvement can be defined as a process under which given traits are changed in a favourable direction over generations by alteration of the underlying genes (Namkoong et al. 1988). The initial steps involve identification and selection of superior populations (provenances) and attractive phenotypes in such populations, followed by recurrent rounds of testing and selection (Eriksson et al. 2006). The approach includes four important 
phases: (1) the screening and mobilisation phase, where populations and individuals with desired phenotypic traits are identified and selected; (2) the testing phase where the individuals are evaluated and selected; (3) the breeding phase where superior genotypes are crossed either by controlled or random mating; followed by (4) the recurrent phase where progenies from these crosses are tested in the field, new selections made, crossed and evaluated over successive generations. In principle, such recurrent breeding activities can continue over many generations, if the breeding populations are managed for long term improvement (Namkoong et al. 1988). Gain in each recurrent breeding cycle (progenies compared to the parent generation) may be large or modest, but the progress of the breeding programmes will in the long run depend on the gain per year, i.e. the gain per selection cycle divided by its length. A key parameter for the potential of breeding is therefore time required for proper testing and/or the age at which seed set starts (generation time). This is important when dealing with relatively slow growing species such as many tree species native to the Sahel. Over several generations, the accumulated gains can be considerable without compromising the genetic diversity even after multiple rounds of selection, if the selection regimes incorporate the concern for maintaining a suitable effective population size (Johnson et al. 2001).

Even strong selection intensity in a population showing high phenotypic variability will only lead to substantial gains if the heritability is of acceptable size, because the gain depends on the product between selection intensity, heritability and within population variation (Eriksson et al. 2006). Knowledge of the heritability and the phenotypic variability for different fruit characters is therefore important in order to determine which traits are worth selecting for. At present, data on heritability $\left(h^{2}\right)$ of fruit traits lack for all major native West African Sahelian fruit trees as will be discussed below. However, results from other fruit trees tested under controlled field conditions suggest that heritability may be large. Silva et al. (2007) found quite high narrow sense heritability for fruit weight $\left(h^{2}=0.60\right)$ in the early domestication phase of Custard Apple (Annona squamosa L.) in North Eastern Brazil. Based on selected commercial cultivars of Guava (Psidium guajava L.), Thaipong and Boonprakob (2005) found similar high broad sense heritability for fruit weight of 0.65 in Thailand. In North-Eastern Australia, Hardner et al. (2001) estimated similar broad sense heritability in kernel weight (0.64) of Macadamia nuts (Macadamia integrifolia Maiden and Betche and M. tetraphylla L.A.S. Johnson). Strong genetic components behind the observable phenotypic variation has also been found for several domesticated subtropical and temperate fruit species such as Hazelnut (Corylus avelana L) where Yao and Mehlenbacher (2000) found heritability for fruit size above 0.6. Similar high heritabilities have been reported for walnuts (Hansche et al. 1972) and almonds (Kester et al. 1977; Chandrababu and Sharma 1999), while somewhat smaller heritability $\left(h^{2}=0.35\right)$ was reported for pecan nuts (Thompson and Baker 1993).

\section{Status for domestication of Sahelian fruit trees in West Africa}

A number of studies have laid the foundations for domestication, by clarifying the role of fruit trees for rural livelihoods (e.g. Leakey and Simons 1998; Schreckenberg et al. 2006), and setting priorities for domestication (Franzel et al. 2008). Also, efforts have been made to develop vegetative propagation for $P$. biglobosa and $V$. paradoxa (Teklehaimanot et al. 1996; Sanou et al. 2004). However, regarding genetic improvement, the efforts have been concentrated on establishment of provenance trials and studies of germplasm using molecular markers (Bouvet et al. 2004; Fontaine et al. 2004; Sanou et al. 2005; Sina 2006; 
Assogbadjo et al. 2006; Diallo et al. 2007). As for published results on genetic variation in adaptive traits and fruiting, they are rather difficult to find.

Kalinganire et al. (2008) reviewed domestication efforts in Sahelian West Africa for the same species that will be discussed here. However, since submission of that paper, new research projects have been initiated including the projects DADOBAT, INNOVKAR, SAFRUIT, NUTREE and the ICRAF/IFAD project 'Programme for strengthening livelihood strategies in the West African Sahel through improved management and utilization of parkland agroforests'. Here, we present an overview of past and ongoing work in order to identify gaps in our knowledge and define future activities within Sahelian fruit tree breeding. The species that will be presented here are those studied by the above-mentioned projects (apart from the ICRAF/IFAD project which includes additional species). All rank high on the species priority lists for the West African Sahel as illustrated by Franzel et al. (2008). We will discuss the status of domestication considering collection, characterisation, evaluation and conservation of germplasm, knowledge of genetic parameters and mating systems, and development of vegetative propagation.

\section{Adansonia digitata}

In human nutrition, A. digitata is used for its leaves (in sauces), fruit pulp and seeds. Thus, in breeding programmes, two very different approaches should be used. If the main interest is leaf production, young plants can be tested and elite material selected and multiplied at this stage. If fruit characters are in focus, mature trees will have to be tested. A thorough review of the importance of the baobab in the Sahel has been presented by Sidibé and Williams (2002). Food composition and nutritional values of $A$. digitata have been reviewed by Chadare et al. (2009). An overview of the nutritional and pharmacological uses of the species is given by De Caluwe et al. (2009). The food potential of A. digitata appears underutilized. It is used daily in rural households as well as commercialized (Sidibé and Williams 2002). Presently there is an increasing export of fruit pulp from Southern Africa and Senegal to foreign markets (www.phytotrade.com; www.baobabfruitco.com).

In 1989, two provenance trials were established in Gonsé and Djibo in Burkina Faso, including accessions from Burkina Faso, Côte-d'Ivoire, Senegal, and Kenya (Diallo, unpublished data). Today, only the test site at Djibo remains operational. The trial has shown remarkable differences in survival between origins, but due to the small sizes of the test plot along with its design, it is difficult to judge whether the observed differences are caused by genetic, environmental, or random variation.

In 2006 and 2007, a collection of provenances was realised by the partners of the SAFRUIT project in the Sahelian West Africa, with a focus on material from Burkina Faso, Mali and Niger. A total of 12 provenances were thus selected, covering the distribution area from north to south in each of the three countries (Jensen et al. this issue). Seeds from different mother trees were kept separately. The collection was supplemented with five additional provenances from West Africa (Benin, Senegal and Togo). Twelve provenances were obtained from East Africa, including Kenya, Malawi, Mozambique, Tanzania and Sudan. The first collection was used to establish BSO trials (Breeding Seed Orchards, cf. Barnes 1995; Dhakal et al. 2005) in Burkina Faso, Mali and Niger, whereas the international collection was used for provenance trials in Mali and Niger. Central West Africa is thus relatively well covered by these germplasm collections, while peripheral West Africa and the rest of the African continent are less intensively covered. Also, there is a need to add collections from the northern (dry) limits of the distribution area. When the DADOBAT project made collections in Senegal, only a few trees were sampled in the 
northern parts because of a low fruit set and because local people had collected and used all available fruits and seed. We are not aware of studies documenting tree regeneration and population structure in these areas, but since the northern populations may be especially adapted to dry conditions, there may be a need to have a special focus on conservation of these populations.

Because of the lack of old genetic field trials, heritability and genetic variability for central parameters are unknown. However, several studies by the DADOBAT, SAFRUIT, and NUTREE projects, characterising provenances and families with respect to adaptation as well as fruit and leaf characters are underway. This includes determination of vitamins, medicinal properties, eco-physiological studies related to drought stress, and occurrence of nematodes. Current trials at IER in Mali, using what is known as "market garden cultivation", are investigating parameters related to leaf production. Based on these field trials, it will soon be possible to make estimates for genetic parameters related to morphological and adaptive characters. Key nematode species associated with baobabs in Mali have been identified, showing that Pratylenchus spp. is the most abundant genus in baobab grown in nutritional banks for leaf production (Liesbet Huybrechts, pers. comm.).

Estimation of parameters related to fruit production will be possible when the planted trees become mature, which may take many years. Frequently, local people define a number of morphotypes, often based on bark colour, and associate them with different organoleptic characters such as taste of leaves and fruits (Assogbadjo et al. 2008; Sanou et al. 2009). Whether there is a correlation between these morphotypes and the characters mentioned remains to be studied, and so does the heritability of these traits. However, a molecular genetic study carried out by Assogbajo et al. (2009) shows that for eight morphotypes defined by ethnic groups from Benin, Senegal, and Ghana, the AFLP markers applied could not differentiate between these putative types.

Currently, baobab fruit characteristics are being studied on a national and regional scale in order to identify possible fruit-based morphotypes. Provided these 'formal' morphotypes are validated, they could be used in strategies for germplasm collection and conservation (SAFRUIT and DADOBAT projects).

Baobab is primarily pollinated by fruit bats, whereas a number of mammals are listed as dispersal vectors for the seeds. These include elephants, primates, and ruminants (Wickens and Lowe 2008). Assogbadjo et al. (2006) studied the genetic diversity in six populations of $A$. digitata from Benin by AFLP markers and found relatively high levels of genetic diversity within populations. Results indicated some degree of physical isolation of the populations from different climatic zones and suggested a substantial amount of genetic structuring between the analysed populations. Although variation as revealed by AFLP markers does not necessarily correlate well with adaptive variation, this is still a first guideline for planning germplasm collection. It remains to be determined whether this differentiation between populations is due to isolation or heavy selection over the environmental gradients going from northern to southern Benin. Assogbadjo et al. (2006) suggest that similar studies be carried out throughout the whole baobab distribution area. Microsatellite markers have been developed (Larsen et al. 2009), and will be used to investigate the breeding system of $A$. digitata. Work is also underway to describe past migration patterns and possibly to infer on the extent to which human influence determined present day distribution of the species.

Data on baobab flower morphology, phenology and pollination are sparse, but a study on controlled pollination and flower morphology in Benin is forthcoming. Another study will look at the germination success of seeds sown under the crown of the mother tree compared to those sown under other tree species (SA Edon, pers. comm.). 
Vegetative propagation by grafting is possible. For adult ortets, chip budding was the most successful technique (Danthu and Soloviev 2000). Presently, micro-propagation techniques are under development (Kambou Sié, pers. comm.). Cross-species grafting tests in Adansonia are very successful resulting in new agroforestry possibilities with different scion/rootstock combinations (Maranz et al. 2008). It is, however, not yet clear whether there will be delayed grafting incompatibility. An overview of the ongoing research and identified gaps is presented in Table 1.

\section{Parkia biglobosa}

The projects PARKLAND and PARKIA collected seed sources from a broad range of West African origins (Teklehaimanot 1997). Three trials were established in the Sahelian West Africa (two in Burkina Faso and one in Nigeria), of which the Burkina Faso trials still exist and represent a unique source of reference material, both for gene conservation and comparative studies. Furthermore, during 2006 and 2007, seeds were collected from plus trees in Burkina Faso and Mali as part of SAFRUIT, and subsequently used in BSO trials in the two countries. It is noteworthy that along the northern limit of the distribution area in Burkina Faso, tree distribution was strongly fragmented, and it was difficult to find large healthy trees in certain areas. Moreover, there are problems of fruit depletion by birds (e.g. parrots) and by communities collecting fruits for their own consumption, thus making seed

Table 1 Status for domestication of A. digitata in West African Sahel

\begin{tabular}{|c|c|c|}
\hline Component & Achievements and ongoing research & Identified gaps in the research \\
\hline $\begin{array}{r}\text { Germplasm } \\
\text { collection }\end{array}$ & $\begin{array}{l}\text { West African collection almost complete } \\
\text { Pan-African collection initiated }\end{array}$ & $\begin{array}{l}\text { Few samples from Eastern, Central and } \\
\text { Southern Africa }\end{array}$ \\
\hline $\begin{array}{l}\text { Genetic } \\
\text { parameters }\end{array}$ & $\begin{array}{l}\text { Parameters for leaf production in progress } \\
\text { Results for growth and adaptation can be } \\
\text { expected soon } \\
\text { Studies of molecular genetic variation are } \\
\text { under way }\end{array}$ & $\begin{array}{l}\text { No parameters for fruit production } \\
\text { Relationship between morpho-types and } \\
\text { genotypes still to be confirmed }\end{array}$ \\
\hline $\begin{array}{l}\text { Characterisation } \\
\text { and evaluation }\end{array}$ & $\begin{array}{l}\text { Provenances and half-sib families are being } \\
\text { established in BSO trials } \\
\text { Eco-physiological stress trials ongoing } \\
\text { (drought) } \\
\text { Studies of vitamin and nutritional values } \\
\text { ongoing } \\
\text { AFLP and micro-satellite markers developed } \\
\text { Phylogeographic study under way along } \\
\text { with local studies of differentiation } \\
\text { between populations }\end{array}$ & $\begin{array}{l}\text { Need to repeat trials in other } \\
\text { environments, and to establish large } \\
\text { international trials }\end{array}$ \\
\hline $\begin{array}{l}\text { Mating systems } \\
\text { and patterns }\end{array}$ & $\begin{array}{l}\text { Marker studies on provenances from Benin } \\
\text { Study of gene flow ongoing } \\
\text { Germination incompatibility under mother } \\
\text { trees being investigated }\end{array}$ & $\begin{array}{l}\text { Detailed studies of pollinators } \\
\text { Test of incompatibility system } \\
\text { Degree of self pollination in populations } \\
\text { Effective population sizes } \\
\text { Presence of inbreeding depression }\end{array}$ \\
\hline Conservation & $\begin{array}{l}\text { Collected germplasm conserved in four trials } \\
\text { with some degree of replication }\end{array}$ & $\begin{array}{l}\text { Need to make more trials, to establish the } \\
\text { complete set of provenances in at least } \\
\text { three sites }\end{array}$ \\
\hline $\begin{array}{l}\text { Vegetative } \\
\text { propagation }\end{array}$ & Grafting and other techniques successful & $\begin{array}{l}\text { Optimization of grafting techniques } \\
\text { Micro-propagation techniques (under } \\
\text { development) }\end{array}$ \\
\hline
\end{tabular}


collection a limiting factor to improving P. biglobosa. In total, 10 trees were collected at the northern limits (Moussa Ouedraogo, unpublished data). Outside Burkina Faso and Mali, there only seem to be few research activities on the species. If the trend from Burkina Faso is general, it would be very important to sample especially the northern distribution range in order to conserve genetic resources of relatively drought tolerant origins.

Estimates of provenance repeatability and variation for morphology, adaptive characters and fruits are under way, using the before mentioned field trials in Burkina Faso (NUTREE and SAFRUIT). Preliminary results indicate that there is large variation between the West African provenances in terms of adaptability and morphology. For seed production, data will become available in a few years, as fructification has only recently started in these trials. Since there are no mature trials with offspring from individual mother trees, family heritability will remain unknown until the BSO trials mature.

The primary pollinators of $P$. biglobosa appear to be bats, but honey bees can act as pollinators too. The species is not autogamous, but self-pollination is possible. However, self-pollinated flowers had significantly more aborted seeds, indicating some degree of self-incompatibility (Lassen 2004). Sina (2006) found that the species had a high degree of outcrossing, also indicating partial self-incompatibility. In his study, flowering took place over a period of 4 months and was largely synchronous. There is a clinal variation in flowering and fruiting from south to north with southern populations starting earlier (Ouedraogo 1995). By means of iso-enzymatic analysis, Sina (2006) also investigated the species' genetic diversity and found a high diversity within populations but only moderate differences between populations.

Vegetative propagation using mature tissue of the species is difficult. Teklehaimanot et al. (1996) succeeded in producing rooted cuttings from seedlings, but had very limited success with mature trees. Furthermore, ongoing studies show low rates of success with grafting. Presently, vegetative propagation of the species does not seem to be an effective means of propagation outside the experimental context. See Table 2 for a status of the domestication activities on the species.

\section{Tamarindus indica}

The principal product of Tamarindus indica is the pulp which is used as an ingredient in cooking and juices. Seeds, leaves, and flowers are also used in human nutrition, and various products of the species have pharmaceutical properties (De Caluwe et al. 2010).

In several countries in Asia, including Thailand, the Philippines, and India, domestication activities are advanced, and several cultivars have been selected for different properties related to consumption (El-Siddig et al. 2006). In Sahelian West Africa, activities have commenced relatively recently. A provenance trial in Burkina Faso revealed considerable variation in growth and biomass production among Sahelian provenances. Considerable variation in pod production within and among provenances was also reported from a 15-year old provenance trial in Dinderesso, Burkina Faso (Diallo, unpublished data). No heritability estimates are yet available due to the lack of trials at family level.

A new collection on separate mother trees was made in 2006 and 2007 in Burkina Faso, Mali and Niger by the SAFRUIT project, yielding a total of 9 provenances and approximately 180 mother trees. This collection has been used to establish BSOs in Burkina Faso, Mali and Niger. Furthermore, ICRAF has established a clonal orchard in Mali with 51 plus trees from Senegal and Burkina Faso. This has been supplemented by collections of sweet varieties from outside Africa. 
Table 2 Status for domestication of P. biglobosa in West African Sahel

\begin{tabular}{|c|c|c|}
\hline Component & Achievements and ongoing research & Identified gaps in the research \\
\hline $\begin{array}{r}\text { Germplasm } \\
\text { collection }\end{array}$ & $\begin{array}{l}\text { Provenance collection by earlier projects } \\
\text { Plus tree selection in Burkina Faso and } \\
\text { Mali }\end{array}$ & $\begin{array}{l}\text { Plus tree selection in other countries, } \\
\text { especially on the Northern limits of the } \\
\text { distribution area }\end{array}$ \\
\hline $\begin{array}{l}\text { Genetic } \\
\text { parameters }\end{array}$ & $\begin{array}{l}\text { Studies of morphology and growth in } \\
\text { progress }\end{array}$ & Missing for all traits related to fruits \\
\hline $\begin{array}{l}\text { Characterisation } \\
\text { and evaluation }\end{array}$ & $\begin{array}{l}\text { Phenotypical parameters for natural } \\
\text { populations available from Burkina Faso } \\
\text { and Mali } \\
\text { Results for adaptive traits and leaf } \\
\text { morphology from provenance trials are } \\
\text { becoming available } \\
\text { Ecophysiological stress trials ongoing }\end{array}$ & $\begin{array}{l}\text { No data on family level } \\
\text { No data on fruits in relation to genotypes }\end{array}$ \\
\hline $\begin{array}{l}\text { Mating systems } \\
\text { and patterns }\end{array}$ & $\begin{array}{l}\text { Pollinators identified } \\
\text { Partly self incompatible } \\
\text { Geneflow for populations? }\end{array}$ & $\begin{array}{l}\text { Pollen flow } \\
\text { Degree of inbreeding } \\
\text { Isolation distances }\end{array}$ \\
\hline Conservation & $\begin{array}{l}\text { Provenance collections exist in Burkina } \\
\text { Faso }\end{array}$ & $\begin{array}{l}\text { Northern populations seem threatened, } \\
\text { need to secure the resource as soon as } \\
\text { possible }\end{array}$ \\
\hline $\begin{array}{l}\text { Vegetative } \\
\text { propagation }\end{array}$ & $\begin{array}{l}\text { Cuttings of young plants possible } \\
\text { Grafting possible, but with low rates of } \\
\text { success }\end{array}$ & $\begin{array}{l}\text { Development of efficient macropropagation } \\
\text { Micropropagation }\end{array}$ \\
\hline
\end{tabular}

Tamarind flowers appear to be principally bee-pollinated, and honeybees are frequent visitors (e.g. Nagarajan et al. 1998; Radhamani et al. 1993). Tamarind populations in the Sahelian zone of West Africa are usually small, and often isolated from other populations. Isolated trees also occur in the landscape as a consequence of seed dispersal by humans and domesticated or wild animals (Aubréville 1950). While fruit production appears to be higher in trees located near other $T$. indica trees, even isolated trees sometimes produce fruits. This suggests that trees might be self-compatible. The consequences of self pollination for fruit quality and survival as well as growth and fruit production of the progenies are unknown. However, detailed studies show that $T$. indica appears to be at least preferentially outcrossing. Flowers are hermaphroditic, but the spatial arrangement of anthers and stigma may tend to limit self-pollination (Diallo et al. 2008). Also, female flowers precede male flowers by one day. This poses an additional barrier to self-pollination (Bajpai et al. 1968). Studies on phenology and controlled pollination of tamarind have started in Benin and Mali, and first results are expected soon (DADOBAT project).

Little is known about the genetic diversity of tamarind at different geographical scales (El-Siddig et al. 1999). Based on RAPD markers, Diallo et al. (2007) found a high degree of genetic diversity within Asian and African populations. Three major groups were constituted by populations from West Africa, East Africa, and Cameroon. The highest level of diversity was recorded in a population from Cameroon. The high genetic diversity revealed in West African populations indicates that there is no immediate risk of genetic erosion in this region, as long as ecological conditions continue to permit regeneration. Displacement of seed by humans is believed to have played a major role in shaping the distribution of the species and the observed pattern of diversity. Though the species is believed by many to have its origin in Africa (references in El-Siddig et al. 2006), Diallo et al. (op. cit.) found no conclusive evidence for this. 
In Senegal, eco-physiological behaviour of $T$. indica is presently being studied: a few individual trees are characterised in situ and seedlings from several agro-ecological zones are characterised under greenhouse conditions subjected to drought stress. Similar experiments are underway with $T$. indica accessions from Mali (DADOBAT).

The species can be propagated by different sorts of vegetative propagation, including grafting, cutting, and layering (Danthu and Soloviev 2000; El-Siddig et al. 2006). In Mali, methods like rooted cuttings and layering gave modest results (Kone Bréhima, pers. comm.). Presently, studies are underway to develop simple technologies for vegetative propagation, applicable to farmers (SAFRUIT ongoing research). Preliminary results show that grafting is relatively successful. Table 3 presents an overview of the achievements and gaps in research for $T$. indica.

\section{Vitellaria paradoxa}

Vitellaria paradoxa is used for firewood and charcoal, whereas fruit flesh is consumed fresh. Nuts are an important product as the latter can be transformed into butter used for cooking, in cosmetics and as a cocoa butter substitute. Natural V. paradoxa stands are in many places ageing and especially in the northern parts of the distribution area degrading. Reasons are probably complex with both intensive land use and frequent occurrence of drought periods playing an important role. The EU-funded INNOVKAR project attempts to improve management recommendations for $V$. paradoxa parklands based on their ability to face drought and by prediction of the distribution of shea tree under future climatic scenarios. The work follows three approaches, including (1) characterisation of abiotic variables, tree phenology and ${ }^{13} \mathrm{C}$ discrimination of $V$. paradoxa populations across their natural range; (2) analysis of tree structure, morphological and eco-physiological traits in nursery experiments with three water regimes, combined with carbon budget estimation of trees in natural parkland systems; and (3) modelling of changes in the distribution of shea tree under different climate change scenarios (Bayala et al. 2008).

The species appears to perform best in agricultural settings. Lamien et al. (2004) conducted a study aimed at comparing fruit production of shea nut trees located in

Table 3 Status for domestication of T. indica in West African Sahel

\begin{tabular}{|c|c|c|}
\hline Component & Achievements and ongoing research & Identified gaps in the research \\
\hline $\begin{array}{r}\text { Germplasm } \\
\text { collection }\end{array}$ & $\begin{array}{l}\text { Existing provenance trials } \\
\text { Collection of half-sib families in } \\
\text { Burkina Faso, Mali and Niger }\end{array}$ & $\begin{array}{l}\text { Provenance and half-sib collections from the } \\
\text { rest of the distribution area }\end{array}$ \\
\hline Genetic parameters & No information & $\begin{array}{l}\text { Lack of information on phenotypic } \\
\text { variability and heritability }\end{array}$ \\
\hline $\begin{array}{l}\text { Characterisation } \\
\text { and evaluation }\end{array}$ & $\begin{array}{l}\text { Adaptive and fruit traits from } \\
\text { provenance trials } \\
\text { Ecophysiological stress trials }\end{array}$ & No information at family level \\
\hline $\begin{array}{l}\text { Mating systems } \\
\text { and patterns }\end{array}$ & $\begin{array}{l}\text { Studies of pollination in Burkina Faso } \\
\text { Gene flow } \\
\text { Self-incompatibility }\end{array}$ & $\begin{array}{l}\text { Degree of inbreeding } \\
\text { Effective population sizes } \\
\text { Isolation distances }\end{array}$ \\
\hline Conservation & Provenance trials and new BSO trials & $\begin{array}{l}\text { Need to include the rest of the distribution } \\
\text { area (see germplasm collection) }\end{array}$ \\
\hline $\begin{array}{l}\text { Vegetative } \\
\text { propagation }\end{array}$ & Macro-propagation developed & Micro-propagation \\
\hline
\end{tabular}


agroforestry parklands to those present in natural habitats. Results revealed that $94 \%$ of trees located in agroforestry parklands produced fruits against only $56 \%$ of trees located in natural habitats. Average kernel yield of trees located in agroforestry parklands was $167 \%$ higher than that of trees located in natural stands. Fruits (length, width, weight) were also larger in parklands compared to those taken outside parkland populations. The same was found in a study from Mali (Kalinganire, unpublished data). Insect infestation of shoots and fruits was shown to be more serious in a site close to a natural forest than in a site further away, and is likely to have an impact on fruit production (Lamien et al. 2008). Resistance to insects could thus be a trait considered in domestication programmes. Mistletoe (Loranthaceae) infestation which is present on most $V$. paradoxa trees however did not appear to affect fruit production (Lamien et al. 2006).

Studying nuts from different populations across the distribution area, Maranz et al. (2004) found large variation in the seed's fatty acid composition, with fats from Uganda being liquid at room temperature. In West Africa, the composition is variable both between and within populations, with the hardest butter obtained in central Burkina Faso.

A trial with five provenances from Burkina Faso, Mali and Senegal is located in Burkina Faso. The aim was to address issues such as the long juvenile phase and large variability in annual fruit yields. Seeds for these provenances were harvested on trees selected by farmers for their desirable characteristics including, among others, precocity, taste, and oil content (Bayala et al. 2009). Analysis after 6 years revealed significant differences among provenances for tree height, collar diameter, transpiration rates, and number of leaves. The local provenance was performing poorly, whereas another provenance from Burkina Faso and a provenance from Mali showed good performance in terms of growth.

ICRAF in Mali has a collection of 110 plus trees (clones) from Burkina Faso, Benin, Nigeria, Ghana, Cameroun, Niger, and Mali. The INNOVKAR project made a new collection of germplasm, including material from Burkina Faso, Ghana, Mali, Senegal and Uganda, which has been used for a new provenance trial in Burkina Faso. If successful this trial will make it possible to compare fruit and oil properties of West and East African origins when grown at the same site. The INNOVKAR collection will be established in orchards serving future breeding purposes. Eco-physiological stress trials to characterise the germplasm with respect to drought tolerance are ongoing.

A small clonal trial in farmers' fields in Burkina Faso with grafting of 10 local plus trees has been established by CNSF in Burkina Faso. The trial has shown that flowering is initiated earlier in grafted plants and studies of variation in the fruit set and quality are ongoing. Once completed, calculations of clonal performance will be available. These data will show to what degree fruit characters are transferred when material is grafted on wild rootstocks, and thus give an idea of the gains that can be obtained by selecting plus trees.

Fontaine et al. (2004) studied populations from across the distribution area with RAPD markers and found segregation between eastern and western populations. Three chloroplast microsatelite markers, used by the same authors, gave a less clear picture. Sanou et al. (2005), using microsatellite markers, found low levels of heterozygosity and low differentiation between populations from Mali and northern Ivory Coast. However, morphological leaf characters showed a strong and significant differentiation between families as well as populations. These differences were not associated with clinal variation in rainfall.

In Mali, spatial genetic structure has been assessed (Sanou et al. 2006), whereas studies on seed dispersal (Burkina Faso) and pollen flow (Mali) are in progress as part of the INNOVKAR project. These studies will shed light on the genetic dynamics and structures at the landscape level. 
Vegetative propagation by grafting has been developed, and it was shown that the first grafts produced fruits after just 2 years (Sanou et al. 2004). Layering is also a feasible propagation technique for $V$. paradoxa. The status for existing and ongoing research is presented in Table 4.

\section{Ziziphus mauritiana}

It is believed that $Z$. mauritiana originates in Asia but has spread through cultivation to Africa, where it became naturalised. The species is preserved in farmlands because of its nourishing fruits and is also increasingly planted as a live fence to protect crops grown during the dry season. A survey in Burkina Faso, Mali, Niger, and Senegal revealed that this species is among the farmers' 10 most preferred species (Bonkoungou et al. 1998). However, the small size of the fruit of the local cultivar (1-2 g per fruit) and its sensitivity to pests and diseases limit the adoption of agroforestry techniques based on this species (Ouédraogo 1998; Diallo et al. 2000). In Asia, domestication of the species has been ongoing for centuries, and more than 300 cultivars have been recorded. Asian cultivars typically have large juicy fruits up to $3 \times 5 \mathrm{~cm}$, whereas fruits of the African naturalised origins are much smaller, 1-2 cm in diameter (Azam-Ali et al. 2006). Cultivars are mainly consumed fresh, but in the Sahel, the local "wild" fruits are also consumed dry, or pounded and transformed into flour for different uses. Fruit yield during the first two growing seasons of three Asian varieties was shown to be several times higher than the yield of a local variety in Burkina Faso (Ouedraogo et al. 2006). Research on the species has been synthesised by Azam-Ali et al. (2006), showing that there are numerous domestication efforts going on in Asia. Domestication activities of the species in the Sahelian West

Table 4 Status for domestication of V. paradoxa in West African Sahel

\begin{tabular}{|c|c|c|}
\hline Component & Achievements and ongoing research & Identified gaps in the research \\
\hline $\begin{array}{r}\text { Germplasm } \\
\text { collection }\end{array}$ & $\begin{array}{l}\text { ICRAF clone collection from West Africa } \\
\text { Provenance trial in Burkina Faso } \\
\text { Farmer based selection of superior clones is } \\
\text { taking place } \\
\text { Collection of provenances from Uganda to } \\
\text { Senegal ongoing }\end{array}$ & $\begin{array}{l}\text { Relatively good collection on a regional } \\
\text { scale, but there may be a need to sample } \\
\text { more intensively for locally adapted } \\
\text { material }\end{array}$ \\
\hline $\begin{array}{l}\text { Genetic } \\
\text { parameters }\end{array}$ & $\begin{array}{l}\text { Local studies of genetic variation in } \\
\text { molecular genetic markers as well as fruit } \\
\text { and leaf characters underway } \\
\text { Study of clonal variation ongoing }\end{array}$ & $\begin{array}{l}\text { No information about heritability of fruit } \\
\text { characters }\end{array}$ \\
\hline $\begin{array}{l}\text { Characterisation } \\
\text { and evaluation }\end{array}$ & $\begin{array}{l}\text { SSR based studies of genetic differentiation } \\
\text { available } \\
\text { Eco-physiological stress trials ongoing }\end{array}$ & Few genotypes in existing clonal trials \\
\hline $\begin{array}{l}\text { Mating systems } \\
\text { and patterns }\end{array}$ & $\begin{array}{l}\text { Molecular based studies of seed and pollen } \\
\text { dispersal in progress }\end{array}$ & $\begin{array}{l}\text { Degree of inbreeding not established } \\
\text { Incompatibility system }\end{array}$ \\
\hline Conservation & $\begin{array}{l}\text { Provenance trial }+ \text { clone collection } \\
\text { Farmer selected clones will be conserved in } \\
\text { replicated trials }\end{array}$ & Need to duplicate clone selections \\
\hline $\begin{array}{l}\text { Vegetative } \\
\text { propagation }\end{array}$ & Grafting and layering techniques developed & $\begin{array}{l}\text { Other vegetative propagation techniques } \\
\text { are missing } \\
\text { Micropropagation missing }\end{array}$ \\
\hline
\end{tabular}


Africa are recent, and two strategies have been applied: import of cultivars from Asia, and test and selection of local landraces.

Twelve of the Asian varieties have been transferred to West Africa by ICRAF, and five of them are currently being promoted by different institutions in the region (e.g. Ganaba et al. 2007). Ouedraogo et al. (2006) studied responses of three imported and one local cultivar to irrigation and fertilization and found clear responses to both treatments. The SAFRUIT project is currently studying adaptability and yield of five varieties in three agroclimatic zones in Burkina Faso, Mali and Niger.

Six provenance and half-sib family trials of Z. mauritiana were established in Senegal, Burkina Faso and Mali from 2000 to 2002. Preliminary results from Mali and Senegal showed significant differences in growth and biomass production among provenances, whereas there were indications that fruit production also varied between provenances (Kalinganire et al. 2008).

Because Z. mauritiana will fructify after only 2-3 years, the provenance trials mentioned earlier can already be analysed with respect to fruit yield and quality. Studies are ongoing in Mali and will give valuable information about family heritability, provenance, and family variation. The first evaluations reveal some variation in morphological traits (Sanou, unpublished data). In Asia, studies of cultivars have shown high heritability for a number of fruit traits (Azam-Ali et al. 2006). It remains to be confirmed whether this is also true for genotypes from West Africa.

ICRAF has collected more than 70 plus trees from Mali, Niger, Burkina Faso and Senegal that were established in a clonal orchard at Bamako. Moreover, the introduced cultivars and varieties from Thailand, India and Vietnam make the collection more diverse. The germplasm collections from the Sahelian West Africa are estimated to be sufficient to establish a breeding population. However, it may be reasonable to enlarge the collection especially with genotypes from the extremes of the distribution area in order to ensure adaptability in a time with changing climates.

Many of the Asian cultivars appear to be polyploid, whereas the ploidy of African origins seems to be unknown (references in Azam-Ali et al. 2006). Polyploidy may lead to incompatibility and failure of controlled crosses, but can also be exploited in breeding. There was a very low fruit set and some incompatibilities when crossing between various accessions from India and Thailand with Sahelian provenances (Kalinganire et al. this issue). The level and causes of such failures need to be further investigated. Many of the Asian cultivars are self-incompatible, but the situation is not clear for Sahelian sources (Azam-Ali et al. 2006).

Vegetative propagation by both rooted cuttings and grafting is well-developed and is used regularly for propagation of the Asian varieties of the species. Top grafting of improved varieties on wild trees is possible, and is currently being tested at the farmer level in Mali. Preliminary results show that fruit set begins less than a year after grafting (SAFRUIT ongoing research). Micro-propagation and micro-grafting has been developed (Sudhersan et al. 2001; Danthu et al. 2004). Table 5 presents a status for the research on $Z$. mauritiana in the Sahelian West Africa including identified gaps in the research.

\section{Knowledge gaps}

Domestication of fruit trees in the western Sahel has just started, and there is still a long way to go for tree breeders. 
Table 5 Status for domestication of Z. mauritiana in West African Sahel

\begin{tabular}{|c|c|c|}
\hline Component & Achievements and ongoing research & Identified gaps in the research \\
\hline $\begin{array}{r}\text { Germplasm } \\
\text { collection }\end{array}$ & $\begin{array}{l}\text { Collection of plus trees from West Africa } \\
\text { Provenance trials in Senegal, Mali and Burkina } \\
\text { Faso }\end{array}$ & $\begin{array}{l}\text { Expand collections in the extremes } \\
\text { of the distribution area }\end{array}$ \\
\hline Genetic parameters & Estimated for some Asian varieties & Not available for African sources \\
\hline $\begin{array}{l}\text { Characterisation } \\
\text { and evaluation }\end{array}$ & $\begin{array}{l}\text { Ongoing research on provenance trials and half- } \\
\text { sib progeny trials in Mali }\end{array}$ & $\begin{array}{l}\text { Need to repeat trials in other } \\
\text { countries and conditions }\end{array}$ \\
\hline $\begin{array}{l}\text { Mating systems and } \\
\text { patterns }\end{array}$ & $\begin{array}{l}\text { Self incompatibility } \\
\text { Incompatibility between African and Asian } \\
\text { varieties }\end{array}$ & $\begin{array}{l}\text { Degree of inbreeding } \\
\text { Effective population sizes } \\
\text { Hybridization (between improved } \\
\text { and wild varieties) } \\
\text { Phylogeny and relation between } \\
\text { Asian and African origins } \\
\text { Gene flow studies }\end{array}$ \\
\hline Conservation & $\begin{array}{l}\text { Plus tree collection at ICRAF and several } \\
\text { provenance trials in West Africa }\end{array}$ & $\begin{array}{l}\text { Plus tree collection should be } \\
\text { established at other sites }\end{array}$ \\
\hline $\begin{array}{l}\text { Vegetative } \\
\text { propagation }\end{array}$ & $\begin{array}{l}\text { Grafting and different micropropagation } \\
\text { techniques developed }\end{array}$ & \\
\hline
\end{tabular}

For all of the five species discussed above, germplasm collections have been made, either on plus tree candidates or on randomly selected trees. The collections seem to be relatively broad and cover large parts of the distribution areas, especially in Burkina Faso, Mali and Niger. For P. biglobosa, however, collections are limited to Burkina Faso and Mali. Despite the broad collections, there may be reason to make additional collections at the extreme limits of the distribution areas, in particular in the dry zones of the north and the relatively humid areas in the south. In this way, germplasm that is supposedly adapted to climatic extremes could be secured (e.g. Weber et al. 2008).

Unfortunately, much of the collected germplasm is only planted in the field in one or a few sites, making the collections vulnerable to stochastic and catastrophic events. Ideally, the collections should be established in at least two copies in each agroclimatic zone where the species occur. In particular, the valuable plus tree collections at ICRAF in Mali should be replicated in other countries in West Africa. Even more important is that there are no regional or even national plans for conservation of the genetic resources of the different species. Conservation efforts are not coordinated between countries, and are fragmented and depending on externally-funded projects. It is thus difficult to get an overview of the conservation status.

Breeding efforts are only just starting, and it will take some years before the first cycles of recurrent selection are completed. With respect to knowledge of the genetic parameters, there is some information about phenotypic variability, especially with regards to characters related to adaptation. However, information about the heritability of those characters and heritability of fruit characters is almost completely lacking. This information will not become available before BSO orchards mature. Probably the first information will come from studies of $Z$. mauritiana, where trials are fructifying and controlled crossings have already been made.

Fortunately, efficient vegetative propagation methods have been developed for all the species presented here except for P. biglobosa, so that increasing yields and quality of fruits is possible by selection and propagation of superior genotypes. Current activities of 
e.g. the SAFRUIT project aim at developing techniques at the village level, enabling farmers to propagate their own selected material.

Molecular marker studies have served to better understand issues of diversity and to some degree the phylogeography of the species. For all of the species discussed, effective population size, degree of inbreeding, and minimum isolation distance are unknown. Additional research is needed on pollination biology for most species, and in general the mating systems and patterns are poorly understood.

\section{Next steps}

The reports of high genetic variability and heritability from other fruit trees (as discussed above) indicate that substantial gains may be obtained during the selection and testing phases if performed carefully. However, the gain during the initial mobilisation phase (plus tree selection) may be modest for West African Sahelian fruit trees, because the heterogeneous landscape within which the initial selection is performed, different ages, and yearto-tear variation between trees may lead to low heritability. On the other hand, since selection at this stage can be very intensive (1:100 or higher), gains may be substantial for traits of medium or high heritability. Additional gains may be obtained in the mobilisation phase by release of heterosis. Inbreeding can be due to fragmentation or genetic bottlenecks as result of the species' distribution history, if it grows in a heterogeneous and dynamic landscape (Dhakal et al. 2005). In such cases, selection, seed orchard establishment and subsequent cross breeding between trees with different origins may reverse effects from inbreeding depression and release vigour and reproductive fitness. Reproductive energy and success, which may be especially sensitive to inbreeding depression (Wiens et al. 1987), is a key component of productivity in terms of fruit yield. Clarifying the potential of release of inbreeding by crossing geographically distant trees is therefore important.

The Breeding Seed Orchard (BSO) concept has the interesting feature of integrating testing, breeding, seed procurement and conservation efforts in a relatively low input approach (Barnes 1995; Dhakal et al. 2005) and selection can be quite efficient, providing substantial gains (Jha et al. 2006). BSOs established with a relatively large number of provenances and families can provide the necessary infrastructure for testing, selection, estimation of genetic parameters, breeding (controlled or open pollination), genetic management and seed procurement (Barnes 1995). The approach can be combined with clonal deployment of superior genotypes identified at any stage in the improvement cycles, and is currently a part of the domestication strategy of P. biglobosa in Burkina Faso.

The potentials in recurrent selection programmes for breeding of Sahelian fruit trees are limited by the relatively long expected time until first fruiting for many of the species. Gains from selection of superior phenotypes in the field may be harvested sooner if these selected individuals are vegetatively propagated and deployed directly as clones without any additional breeding. In this way the full genetic variation (additive and non-additive) is transferred from the selected trees to the grafted plants, allowing utilisation of any genetic variation that is due to a unique combination of genes at different loci. This is important where specific combinations of taste, fruit size and appearance are desired, and there is a number of potential advantages by using the clonal material directly for African fruit trees (Leakey and Akinnifesi 2008). In the initial stages of domestication (the mobilisation phase) clonal deployment seems especially attractive when outstanding individuals can be identified in wild populations, and the characteristics of such trees easily duplicated. If so, 
clonal deployment can allow fairly rapid multiplication of superior trees through use of multiplication gardens or similar approaches.

Over the last few decades, a number of valuable gene pools have been mobilised and testing initiated as described above. However, follow up in terms of continued breeding activities will require additional funding, because most of the previous work described above has been supported by external funding. It is therefore fair to assume that National agricultural research institutions only have sufficient funding to exploit the results of the established trials and germplasm collections, if they are enrolled in larger projects. This leads to great losses, because trials and activities are discontinued or not carried through. There are numerous trials for which data were never analysed or published, and unfortunately there are also many examples of data or trials being wasted because documentation disappeared. It requires long term commitment and continuity to carry out domestication, and a stable financial situation appears to be one of the prerequisites for efficient breeding programmes. Advanced breeding in temperate fruit tree species has involved testing of thousands of individuals, descending from controlled crosses. It is important to build capacity at national institutions in the Sahelian West Africa to carry out long term activities on this scale. Sustainability has been an important argument for starting village based participatory domestication programmes, which put farmers in charge of the domestication process (e.g. Tchoundjeu et al. 2010).

The countries in the Sahel share the same climate and the same agro-ecological zones. Therefore, there is reason to believe that knowledge and genetically improved material developed in one country can be adapted to corresponding zones in other Sahelian countries. Today, collaboration on domestication across borders is mediated by ICRAF Sahel, whereas collaboration also takes place within the context of the different projects. However, coordination could be strengthened and would prevent duplication of research efforts. Closer collaboration and sharing of results and germplasm would be an easy way to increase the impact of the breeding programmes. One of the priorities thus must be to enhance networking and collaboration between national institutions and researchers when it comes to fruit tree research. In this respect, the roles of fora such as FARA (Forum for Agricultural Research in Africa), PROKARITE, the Sub-Sahara Africa Challenge Programme (SSA-CP), and the SAFORGEN networks should be analysed.

Reaching out to farmers with improved material is another problem. CNSF, the National Seed Centre in Burkina Faso, is diffusing large amounts of seed and plants to state services, NGOs and projects, and also to some degree to individuals. Yet, surveys show that in rural areas, farmers predominantly use seed and plants collected in their own fields or in nearby villages (Ræbild et al. 2005). Few of the farmers interviewed had received seed from $\mathrm{CNSF}$, and it appears that improved seed and varieties are only slowly diffusing out in the country. In neighbouring countries where tree seed centres are smaller or non-existent, the situation can only be expected to be more difficult. There is a need to develop pathways for efficient distribution of seeds and plants to farmers in order for domestication efforts to have any effect whatsoever. Such strategies could build on the commonly adopted farmerto-farmer exchange of germplasm, but it seems that a variety of dissemination channels will have to be used to efficiently diffuse seeds and plants. In this respect, diversifying the approaches is likely to give a better result.

Acknowledgments The research underlying this paper originates in several projects, supported by various sources: The Sahelian Fruit Tree project (SAFRUIT, supported by the European Union's Sixth Framework Programme, contract no. INCO-CT-2005-015465), the NUTREE project (supported by the Danish Council for Development Research), the DADOBAT project (Domestication And Development Of Baobab And 
Tamarind, supported by the European Union's Sixth Framework Programme, INCO contract no. 032217), and the ICRAF/IFAD project "Programme for strengthening livelihood strategies in the West African Sahel through improved management and utilization of parkland agroforests". We gratefully acknowledge their support.

Open Access This article is distributed under the terms of the Creative Commons Attribution Noncommercial License which permits any noncommercial use, distribution, and reproduction in any medium, provided the original author(s) and source are credited.

\section{References}

Assogbadjo AE, Kyndt T, Sinsin B, Gheysen G, Van Damme P (2006) Patterns of genetic and morphometric diversity in baobab (Adansonia digitata) populations across different climatic zones of Benin (West Africa). Ann Bot 97:819-830

Assogbadjo AE, Kakai RG, Chadare FJ, Thomson L, Kyndt T, Sinsin B, Van Damme P (2008) Folk classification, perception, and preferences of baobab products in West Africa: consequences for species conservation and improvement. Econ Bot 62:74-84

Assogbajo AE, Kyndt T, Chadare FJ, Sinsin B, Gheysen G, Eyog-Matig O, Van Damme P (2009) Genetic fingerprinting using AFLP cannot distinguish traditionally classified baobab morphotypes. Agrofor Syst 75:157-165

Aubréville A (1950) Flore Forestière Soudano Guinéenne. Société d'éditions Maritimes et Coloniales, Paris

Azam-Ali S, Bonkoungou E, Bowe C, deKock C, Godara A, Williams JT (2006) Ber and other jujubes. Centre for Underutilized Crops, Southampton

Bajpai PN, Singh RD, Shukla RK (1968) Studies on the floral biology of imli (Tamarindus indica Linn.). Agra Univ J Res 17:149-159

Barnes RD (1995) The breeding seedling orchard in the multiple population breeding strategy. Silv Gen 44:81-88

Bayala J, Ouedraogo SJ, Teklehaimanot Z (2008) Rejuvenating indigenous trees in agroforestry parkland systems for better fruit production using crown pruning. Agrofor Syst 72:187-194

Bayala J, Ouédraogo SJ, Ong CK (2009) Early growth performance and water use of planted West African provenances of Vitellaria paradoxa C.F. Gaertn (karité) in Gonsé, Burkina Faso. Agrofor Syst 75:117-127

Bonkoungou E, Djimde M, Ayuck E, Zoungrana I, Tchoundjeu Z (1998) Taking stock of agroforestry in the Sahel. Harvesting results for the future. End of phase report: 1989-1996. ICRAF, Nairobi

Bouvet JM, Fontaine C, Sanou H, Cardi C (2004) An analysis of the pattern of genetic variation in Vitellaria paradoxa using RAPD markers. Agrofor Syst 60:61-69

Chadare FJ, Linnemann AR, Hounhouigan JD, Nout MJR, Van Boekel MAJS (2009) Baobab food products: A review on their composition and nutritional value. Crit Rev Food Sci Nutr 49:254-274

Chandrababu RJ, Sharma RK (1999) Heritability estimates in almond [Prunus dulcis (Miller) D.A. Webb]. Sci Hortic 79:237-243

Danthu P, Soloviev P (2000) Propagation par greffage de trois espèces forestières fruitières des zones tropicales sèches: Adansonia digitata, Balanites aegyptiaca et Tamarindus indica. Le Flamb 53:22-24

Danthu P, Touré MA, Soloviev P, Sagna P (2004) Vegetative propagation of Ziziphus mauritiana var. Gola by micrografting and its potential for dissemination in the Sahelian Zone. Agrofor Syst 60:247-253

De Caluwe E, Halamová K, Van Damme P (2009) Adansonia digitata L.: a review of traditional uses, phytochemistry and pharmacology. In: Juliani HR, Simon JE, Ho CT (eds) African natural plant products: discoveries and challenges in quality control. American Chemical Society Symposium Series, vol 1021, pp 51-84

De Caluwe E, Halamová K, Van Damme P (2010) Tamarindus indica L.: a review of traditional uses, phytochemistry and pharmacology. Afr Focus 23:53-83

Dhakal LP, Lillesø JPB, Kjær ED, Jha PK, Aryal HL (2005) Seed sources of agroforestry trees in a farmland context: a guide to tree seed source establishment in Nepal. Forest \& Landscape Denmark, Hørsholm

Diallo BO, Sanon J, Some DM, Cao TV, Asimi S (2000) Rapport d'activité final. Projet FAC no 94/CD/78/ BKA Volet 1: Amélioration génétique des ligneux soudano-saheliens. INERA, Ouagadougou

Diallo BO, Joly HI, McKey D, Hossaert-McKey M, Chevallier MH (2007) Genetic diversity of Tamarindus indica populations: any clues on the origin from its current distribution? Afr J Biotechnol 6:853-860

Diallo BO, McKey D, Chevallier MH, Joly HI, Hossaert-Mckey M (2008) Breeding system and pollination biology of the semidomesticated fruit tree, Tamarindus indica L. (Leguminosae: Caesalpinioideae): 
Implications for fruit production, selective breeding, and conservation of genetic resources. Afr J Biotechnol 7:4068-4075

El-Siddig K, Ebert G, Lüdders P (1999) Tamarind (Tamarindus indica L.): a review on a multpurpose-tree with promising future in Sudan. J Appl Bot 73:202-205

El-Siddig K, Gunasena HPM, Prasad BA, Pushpakumara DKNG, Ramana KVR, Vijayanand P, Williams JT (2006) Tamarind-Tamarindus indica L. Southhampton Centre for Underutilised Crops, Sussex

Eriksson G, Ekberg I, Clapham D (2006) Introduction to forest genetics, 2nd edn, Uppsala

Fontaine C, Lovett PN, Sanou H, Maley J, Bouvet JM (2004) Genetic diversity of the shea tree (Vitellaria paradoxa C.F. Gaertn), detected by RAPD and chloroplast microsatellite markers. Hered 93:639-648

Franzel S, Akinnifesi FK, Ham C (2008) Setting priorities among indigenous fruit tree species in Africa: examples from southern, eastern and western Africa Regions. In: Akinnifesi FK, Leakey RRB, Ajayi OC, Sileshi G, Tchoundjeu Z, Matakala P, Kwesiga F (eds) Indigenous fruit trees in the tropics: domestication, utilization and commercialization. CABI, Oxfordshire, pp 1-27

Ganaba S, Kieni B, Barry H, Coulibaly B (2007) Introduction of jujube tree (Ziziphus mauritiana Lam.) cultivars in the Sahelian zone of Burkina Faso. Fruits 62:247-254

Garrity D (2008) Foreword. In: Akinnifesi FK, Leakey RRB, Ajayi OC, Sileshi G, Tchoundjeu Z, Matakala $\mathrm{P}$, Kwesiga $\mathrm{F}$ (eds) Indigenous fruit trees in the tropics: domestication, utilization and commercialization. CABI, Oxfordshire, pp xvii-xviii

Hansche PE, Beres V, Forde HI (1972) Estimates of quantitative genetic parameters and their implications for cultivar improvement. J Am Soc Hort Sci 97:279-285

Hardner C, Winks C, Stephenson R, Gallagher E (2001) Genetic parameters for nut and kernel traits in macadamia. Euphytica 117:151-161

Jha JP, Dhakal LP, Kjaer ED, Lillesø J-PB (2006) Improving productivity of Bauhinia purpurea for tree planting farmers in Nepal. Agrofor Syst 67:273-278

Johnson R, St. Clair B, Lipow S (2001) Genetic conservation in applied tree breeding programs. In: Bart A, Thielges BA, Sastrapradja SD, Rimbawanto A (eds) Proceedings of the ITTO conference on in situ and ex situ conservation of commercial tropical trees. IITO, Yogyakarta, pp 215-230

Kalinganire A, Weber JC, Uwamariya A, Kone B (2008) Improving Rural Livelihoods through Domestication of Indigenous Fruit Trees in the Parklands of the Sahel. In: Akinnifesi FK, Leakey RRB, Ajayi OC, Sileshi G, Tchoundjeu Z, Matakala P, Kwesiga F (eds) Indigenous fruit trees in the tropics: domestication, utilization and commercialization. CABI, Oxfordshire, pp 186-203

Kester DE, Hansche PE, Beres V, Asay RN (1977) Variance components and heritability of nut and kernel traits in almond. J Am Soc Hort Sci 102:264-266

Lamien N, Ouedraogo SJ, Diallo OB, Guinko S (2004) Productivité fruitière du karité (Vitellaria paradoxa Gaertn. C. F., Sapotaceae) dans les parcs agroforestiers traditionnels au Burkina Faso. Fruits 59:1-7

Lamien N, Boussim JI, Nygard R, Ouédraogo JS, Odén PC, Guinko S (2006) Mistletoe impact on Shea tree (Vitellaria paradoxa C.F. Gaertn.) flowering and fruiting behaviour in savanna area from Burkina Faso. Env Exp Bot 55:142-148

Lamien N, Tigabu M, Dabiré R, Guinko S, Oden PC (2008) Insect (Salebria sp.) infestation and impact on Vitellaria paradoxa C.F. Gaertn. fruit production in agroforestry parklands. Agrofor Syst 72:15-22

Larsen AS, Vaillant A, Verhagen D, Kjær ED (2009) Eighteen SSR primers for tetraploid Adansonia digitata and its relatives. Conserv Genet Resour 1:325-328

Lassen KM (2004) Pollination of Parkia biglobosa in the Gambia, with focus on honeybees as pollinators. MSc Thesis, The Royal Veterinary and Agricultural University, Copenhagen

Leakey RRB, Akinnifesi FK (2008) Towards a domestication strategy for indigenous fruit trees in the tropics. In: Akinnifesi FK, Leakey RRB, Ajayi OC, Sileshi G, Tchoundjeu Z, Matakala P, Kwesiga F (eds) Indigenous fruit trees in the tropics: domestication, utilization and commercialization. CABI, Oxfordshire, pp 28-49

Leakey RRB, Simons AJ (1998) The domestication and commercialization of indigenous trees in agroforestry for the alleviation of poverty. Agrofor Syst 38:165-176

Lovett PN, Haq N (2000) Evidence for anthropic selection of the Sheanut tree (Vitellaria paradoxa). Agrofor Syst 48:273-288

Maranz S, Wiesman Z, Bisgaard J, Bianchi G (2004) Germplasm resources of Vitellaria paradoxa based on variations in fat composition across the species distribution range. Agrofor Syst 60:71-76

Maranz S, Niang A, Kalinganire A, Konaté D, Kaya B (2008) Potential to harness superior nutritional qualities of exotic baobabs if local adaptation can be conferred through grafting. Agrofor Syst 72:231-239

Nagarajan B, Nicodemus A, Mandal AK, Verma RK, Gireesan K, Mahadevan NP (1998) Phenology and controlled pollination studies in Tamarind. Silvae Genet 47:237-241 
Namkoong G, Kang HC, Brouard JS (1988) Tree breeding: principles and strategies. Monographs on Theoretical and Applied Genetics, vol 11. Springer, New York

Ouedraogo AS (1995) Parkia biglobosa (leguminosae) en Afrique de l'Ouest: Biosystematique et Amelioration. Dissertation, Wageningen University

Ouédraogo SJ (1998) Etat des connaissances et perspectives de recherche sur les fruitiers forestiers au Burkina Faso. In: Haq N, Atkinson M (eds) Tropical and sub-tropical fruits of west Africa. Proceedings of 1st regional meeting on tropical and sub-tropical fruits of West Africa, Accra, 15-16 Oct 1998. International Centre for Underutilized Crops, Southampton, pp 21-60

Ouedraogo SJ, Bayala J, Dembélé C, Kaboré A, Kaya B, Niang A, Somé AN (2006) Establishing jujube trees in sub-Saharan Africa: response of introduced and local cultivars to rock phosphate and water supply in Burkina Faso, West Africa. Agrofor Syst 68:69-80

Radhamani A, Nicodemus A, Nagarajan B, Subramanian KN (1993) Reproductive biology and breeding system studies in Tamarindus indica L. In: Veeresh GK, Shaanker RU, Ganeshaiah KN (eds) Pollination in tropics. International Union for The Study of Social Insects, Bangalore, pp 33-35

Ræbild A, Belem B, Lillesø JPB, Yago EL, Damas P (2005) Farmers' planting practices in Burkina Faso. Forest \& Landscape Denmark, Hørsholm

Rey J-Y, Diallo TM, Vannière H, Didier C, Kéita S, Sangaré M (2004) La mangue en Afrique de l'Ouest francophone. Fruits 59:121-129

Sanou H, Kambou S, Teklehaimanot Z, Dembele M, Yossi H, Sina S, Djingdia L, Bouvet J-M (2004) Vegetative propagation of Vitellaria paradoxa by grafting. Agrofor Syst 60:93-99

Sanou H, Lovett PN, Bouvet JM (2005) Comparison of quantitative and molecular variation in agroforestry populations of the shea tree (Vitellaria paradoxa CF Gaertn) in Mali. Mol Ecol 14:2601-2610

Sanou H, Picard N, Lovett PN, Denbélé M, Korbo A, Diarisso D, Bouvet J-M (2006) Phenotypic variation of agromorphological traits of the shea tree, Vitellaria paradoxa C.F. Gaertn., in Mali. Genet Resour Crop Evol 53:145-161

Sanou H, Korbo A, Diami S, Ræbild A, Jensen JS (2009) Prospections et collectes des écotypes de baobab (Adansonia digitata L.) au Mali. Plant Genet Resour Newslett 155:25-34

Schreckenberg K, Awono A, Degrande A, Mbosso C, Ndoye O, Tchoundjeu Z (2006) Domesticating indigenous fruit trees as a contribution to poverty reduction. For Trees Livelihoods 16:35-51

Sidibé M, Williams JT (2002) Fruits for the future-Baobab. International Centre for Underutilised Crops, Southhampton

Silva PSLE, Antonio RP, Mariguele KH, Silva KMBE, De Lima LK, Silva JCD (2007) Estimates of genetic parameters for fruit yield and quality in custard apple progenies. Rev Bras Frutic 29:550-558

Sina S (2006) Reproduction et Diversité Génétique chez Parkia biglobosa (Jasq.) G. Don. Dissertation, Wageningen University

Sudhersan C, AboEl-Nil M, Hussain J (2001) In vitro propagation of Ziziphus mauritiana cultivar Umran by shoot tip and nodal multiplication. Curr Sci 80:290-292

Tchoundjeu Z, Atangana A, Asaah E, Tsobeng A, Facheux C, Foundjem D, Mbosso C, Degrande A, Sado T, Kanmegne J, Mbile P, Tabuna H, Anegbeh P, Useni M (2008) Domestication, utilization and marketing of indigenous fruit trees in West and Central Africa. In: Akinnifesi FK, Leakey RRB, Ajayi OC, Sileshi G, Tchoundjeu Z, Matakala P, Kwesiga F (eds) Indigenous fruit trees in the tropics: domestication, utilization and commercialization. CABI, Oxfordshire, pp 171-185

Tchoundjeu Z, Degrande A, Leakey RRB, Simons T, Nimino G, Kemajou E, Asaah E, Facheux C, Mbile P, Mbosso C, Sado T, Tsobeng A (2010) Impact of participatory tree domestication on farmer livelihoods in West and Central Africa. For Trees Livelihoods 19:217-234

Teklehaimanot Z (1997) Germplasm conservation and improvement of Parkia biglobosa (Jacq.) Benth. for multipurpose use. Final report of EU-INCO research contract TS3*-CT92-0072, 1993-97. University of Wales, Bangor

Teklehaimanot Z, Tomlinson H, Lemma T, Reeves K (1996) Vegetative propagation of Parkia biglobosa (Jacq) Benth, an undomesticated fruit tree from West Africa. J Hort Sci 71:205-215

Thaipong K, Boonprakob U (2005) Genetic and environmental variance components in guava fruit qualities. Sci Hortic 104:37-47

Thompson TE, Baker JF (1993) Heritability and phenotypic correlations of six pecan nut characteristics. J Am Soc Hort Sci 118:415-418

Weber JC, Larwanou M, Abasse T, Kalinganire A (2008) Growth and survival of Prosopis africana provenances tested in Niger and related to rainfall gradients in the West African Sahel. For Ecol Manag 256:585-592

Wickens GE, Lowe P (2008) The baobabs: Pachycauls of Africa, Madagascar and Australia. Springer, Berlin 
Wiens D, Calvin CL, Wilson CA, Davern CI, Frank D, Seavey SR (1987) Reproductive success, spontaneous embryo abortion, and genetic load in flowering plants. Oecologia 71:501-509

Yao Q, Mehlenbacher SA (2000) Heritability, variance components and correlation of morphological and phenological traits in hazelnut. Plant Breed 119:369-381 